\title{
Cloxacillin Sodium Anhydrous
}

National Cancer Institute

\section{Source}

National Cancer Institute. Cloxacillin Sodium Anhydrous. NCI Thesaurus. Code C76222.

The anhydrous form of the sodium salt of cloxacillin, a semisynthetic beta-lactamase resistant penicillin antibiotic with antibacterial activity. Cloxacillin binds to and inactivates penicillin-binding proteins (PBPs) located on the inner membrane of the bacterial cell wall, thereby preventing the cross-linkage of peptidoglycans, which are critical components of the bacterial cell wall. This leads to an interruption of the bacterial cell wall and causes bacterial cell lysis. 